\title{
Privatization of State Owned Enterprises in The Welfarestate Perspective
}

\author{
Tuti Widyaningrum ${ }^{1}$ and Rike Yunita Budi Hutami ${ }^{2}$ \\ ${ }^{1}$ Faculty of Law, University of 17 Agustus 1945, Jakarta, Indonesia \\ ${ }^{2}$ Faculty of Law, University of 17 Agustus 1945, Jakarta, Indonesia
}

\begin{abstract}
This paper proposed an analytical study and investigation about State-owned enterprises (SOEs) privatization policy against welfare state perspective. Other than having an economic impact it also led to a constitutional polemic in Indonesia. So far, privatization of SOEs is considered as the best solution for SOEs to be more productive and efficient when handled by the private sector rather than controlled and managed by the state. However, the negative impact of privatization is not least disadvantageous for the state especially to the people where there are no guarantees and legitimacy from the state responsibility when SOEs has already profit oriented. This research would like to find a new concept of privatization of SOEs in accordance with the welfare state perspective. This research used a normative juridical legal research method. This method was chosen because the object was of norms and doctrines and legal principles related to the title of this research. The Author believes, Privatization has changed the social welfare schemes at as well as distorted the role and responsibilities of the state in realizing common prosperity. The conclusion is the Government should to review all regulations concerning the SOEs privatization and revoke regulations that are contrary to the welfare state principle in Indonesia.
\end{abstract}

\section{Introduction and Literature Review}

The constitution of the Indonesian republic, which is written in Article 33 paragraph (2), stipulates that production branches that are important and control the livelihood of the public are controlled by the state. This is a constitutional mandate to guarantee the realization of a national economy that is able to create social welfare for all Indonesian people. State control in these production branches is realized through the existence of State-Owned Enterprises (SOEs/BUMN). The results of the production branches which are under the auspices of the SOEs privatization are one of the APBN sources for the people welfare.

For implementing of privatization, the government regulates privatization in Law Number 19 of 2003 about SOEs. Then to systematize the privatization effort was formed a Privatization Committee with Presidential Decree Number 18 of 2006 concerning the Committee of Privatization of Corporate Companies (Persero). With the existence of regulations for privatization, the government has privatized SOES almost every year. From 
the Soeharto era to Jokowi's, the policy of SOEs privatization continued more massively. The latest data in 2016, the Commission VI of the House of Representatives (DPR) of the Republic of Indonesia approved the privatization of four state-owned enterprises (BUMN) accompanied by steps of state capital participation (PMN). Namely PT Wijaya Karya (Persero) Tbk for 65.05\%, PT Jasa Marga (Persero) Tbk 70\%, PT Krakatau Steel (Persero) Tbk 80\%, and PT Pembangunan Perumahan (Persero) Tbk with a minimum stake of 51\%.[1].

Recently the government issued Government Regulation (PP) No.72 of 2016 about amendments to PP No.44 of 2005 about Procedures for the Inclusion and Administration of Recently the government issued Government Regulation (PP) No.72 of 2016 about amendments to PP No.44 of 2005 about Procedures for the Inclusion and Administration of State Capital in SOEs and Company In Article 2A paragraph (1) PP No. 72 of 2016 stipulates that the state partnership from state-owned stock in SOEs or other company, has been done by the central government without APBN process. The change of ownership and management of SOEs from the political side has different philosophical implications than to the interests of developing a capitalistic global economy.

\subsection{Privatization Policy}

The word privatization can be traced from its basic word, Prive/Private (English). According to the Indonesian Dictionary, Prive means about or for yourself [2].While Private according to the Oxford Dictionary, is an adjective which means the following, namely Belonging to a person or group, public note; Confidential; Secluded; Not provided by the state. [3]. Whereas according to Sheila B. Kamerman and Alfred J. Khan defines privatization politically as, 1). All shifts in activities or functions from the state to the private sector; 2). all shifts from the public to the private sector in the production of goods and services; and secondly more specifically is the whole shift in the production of goods and services from the public to the private sector. [4]. According to William L. Megginson, as quoted by Coen Husein Pontoh, the purpose of privatization is five: 1) Increase new income for the government; 2). Encourage economic efficiency; 3). Reducing government interference in the economy; 4). Providing opportunities to introduce competition, and 5). Developing capital market [5].

Law Number 19 of 2003 about SOEs in Article 1 of General Provisions number 12 stipulates that, Privatization is the sale of Persero shares, in part or in whole, to other parties in order to improve the performance and value of the company, increase the benefits for the state and society and expanding the ownership of shares by the public. Furthermore, Article 74 paragraph 1 and 2 of Law Number 19 of 2003 about SOEs determines the purpose and aim of privatization are to improve the performance and value added of the company and increase the participation of the public in the ownership of the Persero [6].

The mechanism of privatization is based on Article 3 of the Regulation of the Minister of BUMN No. Per 01/MBU/2010 about the Mechanism of Privatization, Preparation of Annual Programs of Privatization, and Appointment of Supporting Institutions and/or Professionals and other Professions. Privatization can be done by the sale of shares based on Capital Market conditions through 1). Initial public offering (go public); 2). secondary public offering; 3 ). Issuing of convertible bonds and other equity securities; 4). Sale of shares to strategic partners (direct placement) for companies that have registered on the stock exchange or securities; 5) other ways as long as meet certain in the Capital Market [7]. 


\subsection{Welfare State}

The idea of a Welfare state is an antithesis of the liberal state for economic motives. Liberalism is the recognition of the rights to carry out free economic activities and economic exchanges based on private ownership and markets [8]. The Liberals suggest the government does not interfere in the lives of individuals. Even that, the government must guarantee security and order so that individuals could able to free to do their economic activities. But the liberal state only makes benefits for a small group and ignores the interests of the people and tends to be exploitative. Along with the complex needs of the state, has emerged a new understanding of the state is a welfare state. The purpose of the welfare state is to provide welfare to all people. The aim of realizing people's welfare shows that the welfare state is oriented to the public interest so that it is said to be populist [9]. In a welfare state, the state acts actively to fulfilling the welfare of the people. The state must have great power so that it can accomplish the people welfare. As a consequence, the government's has a dual position. On the one hand, the government is as a ruler who makes rules, at the same time the government is a public servant [10].

\section{Objective of the study}

This study aims at investigating the breaches of welfare state principle on the Privatization of SOEs and also analyse the consequences welfare state perspective against people welfare.

\section{Methodology}

This research used normative juridical legal research method. This method was chosen because the object of study was of norms and doctrines and legal principles related to the title of this research. [11] The approach used in this study is a statute approach that used various legal rules as the focus for the central theme of a study [12].

\section{Discussion}

The welfare state is closely related to the obligations and responsibilities of the state in realizing social welfare. As stated by Bung Hatta, in the welfare state is closely related to democracy and popular sovereignty, especially in the economic field. In the pamphlet entitled "Towards an Independent Indonesia", Bung Hatta explained, In the economic democracy, it is no longer a person or a small group that ruled the livelihoods of many people as it is now, but the needs and willingness of many people must be the guideline of companies and income. Therefore, all large income stalks concerning the livelihoods of the people must be based on common property and under the ruled of the people by means of their representative bodies [13]. Based on this, in an effort to manage state wealth in the form of companies that control the lives of many people, it should be accomplished democratically.

As one of the foundations of the national economy, SOEs is seen as a representation of state sovereignty in the economic field. However, the privatization of SOES which opened the gaps in ownership of SOEs to the private sector emerged juridical consequences that differed from the economic calculation of the advantages and disadvantages. At a time when economic conditions were weakening the Government actually issued a non-populist policy by continuing to SOEs privatization. The opening of the role of the private sector, both national and foreign, into the ownership of SOEs will commence the possibility of commercialization of goods and services produced by SOEs. 
The mechanism of privatization ruled based on Article 3 of the Minister of BUMN Regulation No. Per 01/Mbu/2010 about Privatization Method, Preparation of Annual Programs for Privatization, and Appointment of Supporting Institutions and/or Professionals and other Professions is closely related to the capital market regulated in Act No. 8 of 1995. In fact, the sales of SOEs shares based on capital market provisions consist of initial public offering and Right Issue. Direct stock sales to investors can be in the form of strategic sale. From this, it is known that the sale of SOEs shares is prioritized for external interests, especially the interests of investors and the capital market. While the sale of shares directly to the management or employees of the SOE is very rarely done by the government [14].

Such conditions have opened the gap for private ownership of SOEs so that the hope of fulfilling people's welfare is in doubt. This doubt is very reasonable when the profit-oriented private sector will certainly continue to pursue profits for itself without thinking about people's welfare. It is different when the principle of the welfare state puts BUMN as an asset to serve the community. The weak position of the state in SOEs privatization can be seen from two indicators. First, the change in the status of state ownership of goods/services to private ownership so the state loses effective control over its assets. Second, the change in orientation of the profits of the SOEs privatized is used to increasing benefit the company. If you look back at the provisions of Article 33 paragraph (2) of the 1945 Constitution, the state has the right to control over important production branches that are used for the greatest prosperity of the people. However, the mechanism for managing state wealth in the form of SOEs which is accomplish based on the laws and regulations under it has caused distortion meaning of fulfilling people's welfare and tends to be unconstitutional.

This can be seen in PP No. 72 the of 2016 about the amendment to Government Regulation No.44 of 2005 concerning the Procedure for the Inclusion and Administration of State Capital in SOEs and Companies which determines the process partnership in the form of BUMN shares is accomplish by the Central Government without state budget process. In this regulation, the state control of SOEs is increasingly weak because the DPR is no longer involved into supervision of the partnership so that it can become fully private. Besides that, the provisions of Article 1 paragraph (2) PP No.72 of 2016 define that the main purpose of SOEs is to pursue profit, is a fatal mistake because it has shifted the orientation of public services to become commercial so the consequence is the state becomes neglect to the fulfilment of people's welfare.

The dominance of economic liberalization has become the spirit of PP No. 72 of 2016 so the state getting loses the right to control production branches that are important for people welfare. When the mechanism of Partnership in SOEs shares is to do without going through the state budget process, it is a violation of the principle of the welfare state as well as a violation of the provisions of Article 33 paragraph (2) of the Indonesian Constitution. In addition, the provisions of PP No.72 of 2016 also breach Law No.17 of 2003 concerning State Finance because after all the SOEs are state companies that all or part of their capital is owned by the Central Government, where all SOEs activities it related with state finance scope where there is DPR approval is a must. In the implementation of economic democracy, popular sovereignty represented by the DPR has an important role in overseeing the process, targets, and achievements of privatization. When the role of the DPR is ignored, it will certainly eliminate people participation in the supervision of SOEs privatization.

Furthermore, minimization of the role of the state, and added with the absence of DPR control in partnership, will open a possibility hiding selling SOEs by the government. Whereas in Article 24 paragraph (2) Law No. 17 of 2003 about State Finance states that the Government can carry out partnership by first stipulating in the APBN / APBD. When partnership is carried out according to PP No. 72 of 2016, especially Article 2A paragraph (3) and paragraph (4) will result in state assets as referred to in Article 2 paragraph (2) which are used as state partnership in SOEs or company, transformed into shares / state capital to 
the SOE or company, and also the wealth of states transformed as referred to in paragraph (3), becomes the wealth of SOEs or company. This shows that partnership in SOEs shares to the private sector has the same meaning with privatization. Even if privatization, so it must have been approved by DPR, but in fact, DPR has eliminated from this role.

This condition shows a changing in the perspective of national economic development which should refer to mutual cooperation and kinship into economic liberalization which emphasizes on minimizing the role of the state in the economic sector. Ichsanudin Noorsy stated that the one of economic liberalization is about privatization [15]. In the context of the welfare state in Indonesia, the state really has the role of being the administrator and servant of the community which aims to protect the rights of the people from the threat of capitalist domination. The actions of the state are manifested in making regulations and managing the source of the country's wealth to realize the goals of the state as determined in the fourth paragraph of the opening of the Indonesian Constitution, and not making regulations that precisely eliminate the role of the state in the economic democracy.

When the DPR no longer handle its supervisory function in SOEs privatization, then at that time the state has lost the right to control the state in managing, regulating and managing the country's resources. As consequence, state assets that are separated in the form of SOEs partnership according to PP No. 72 of 2016, indirectly that SOEs have been prepared to be privatized or sold. With a non-transparent and undemocratic privatization process, SOEs that are privately owned will be completely free from state control so as not to guarantee the fulfilment of people's rights to the benefits of SOEs.

\section{Conclusion}

Based on the authors' research, it is known that the SOEs privatization policy in PP No. 72 of 2016 tends to the sale of state assets, substantially has consequence changing of public ownership and public assets into private property. This will also change the benefits that the public can own into private benefits. The opening role of both national and foreign private sector in the ownership of SOEs which is practical without effective control from the people (DPR) will only disclose the commercialization of goods and services produced by SOEs, thereby ignoring the fulfilment of benefits in realizing social welfare and justice. The time has come for the Government to review all regulations concerning the SOEs privatization and revoke regulations that are contrary to welfare state economic democracy in Indonesia.

\section{References}

1. BeritaSatu.Com, DPR Setujui Privatisasi 4 BUMN, http://www.beritasatu.com/makro/381612-dpr-setujui-privatisasi-4-bumn.html, accessed on 4 June, 2017.

2. Poerwadarminta WJS, Kamus Besar Bahasa Indonesia, Pusat Bahasa National Education Department, $3^{\text {rd }}$ Edition, 3, (Balai Pustaka, Jakarta, 2006)

3. S. Hawker, Oxford Dictionary and Thesaurus of Current English, (Oxford Dictionary Press, Clays Ltd, Great Britain, 2004)

4. Daeng Salamudin, Privatization: The Foundation of Neoliberal Economic, Artikel, Economic Turmoil, Global Justice Update, Journal Monitoring Globalization and Free Trade, Volume 6/Special Edition, (Institut for Global Justice, Jakarta 2008)

5. P. C. Husein, Akhir Globalisasi; Dari Perdebatan Teori Menuju Gerakan Massa, (C Books, Jakarta, 2003)

6. Law No. 19 Year 2003 concerning State-owned Enterprises 
7. Law No. 8 Year 1995 concerning Capital Market

8. F. Fukuyama, The End of The History and The Last Man, (Qalam, Yogyakarta, 2003)

9. P. S. Hotma, Asas Negara Hukum, (Erlangga, Jakarta, 2010)

10. Sibuea, H. P. (2014). Ilmu Negara. Jakarta: Erlangga.

11. S. Soekanto, Pengantar Penelitian Hukum, (Universitas Indonesia, Jakarta, 2006)

12. J. Ibrahim, Teori \& Metode Penelitian Hukum Normatif, (Bayumedia, Malang, 2005)

13. Santosa Awan, Rezim Ekonomi In-Konstitusional, http://awansantosa.blogspot.com/2007/04/rezim-ekonomi-in-konstitusional.html accessed on 14 June 2018

14. Saragih, J. P, Desentralisasi Fiskal dan Keuangan Daerah Dalam Otonomi. (Ghalia, Jakarta, 2003)

15. Indonesia. Ichsanudin Noersy, JMGFT, 6 (2008) 